\title{
Carotenoid Pigments of Red, Green and Brown Macroalgae Species as Potential Active Pharmaceutical Ingredients
}

\author{
Rashidi Othman*, Nur Alifah Md Amin, Ainaa Eliah Abu Bakar, Nurrulhidayah Ahmad \\ Fadzillah and Noraini Mahmad
}

\author{
International Institute for Halal Research and Training (INHART), Herbarium Unit, Department of Landscape \\ Architecture, Kulliyyah of Architecture and Environmental Design, International Islamic University Malaysia, \\ 53100 Kuala Lumpur, Malaysia
}

\begin{abstract}
Active Pharmaceutical Ingredient (API) is a substance used in a finished pharmaceutical product, intended to furnish pharmacological activity or contribute direct effect in the diagnosis, cure, mitigation, treatment or prevention of disease. It also provides a direct effect in restoring, correcting or modifying physiological functions in human beings. Macroalgae, also known as seaweed, are plant-like organisms that can be found in a marine habitat. Macroalgae has been given huge concern because of its high nutritional value and short-term growth, which is only 45 days per cycle. Therefore, three red macroalgae species of Eucheuma denticulatum, Gracilaria tikvahiae and Kappaphycus striatum), as well as green and brown macroalgae species of Caulerpa lentillifera and Padina pavonica were selected to determine their carotenoids content and composition by using UV-Vis spectrophotometer and HPLC analysis. The main carotenoids identified in red, green and brown macroalgae species were zeaxanthin, lutein, $\beta$-carotene and violaxanthin. Marked differences were observed between red, green and brown macroalgae carotenoids content and composition. Zeaxanthin and $\beta$-carotene were detected in all red, green and brown macroalgae ranged from 3.61 to $21.30 \mu \mathrm{g} / \mathrm{g} \mathrm{DW}$ and 2.44 to $10.70 \mu \mathrm{g} / \mathrm{g}$ DW respectively. Violaxanthin was found only in green macroalgae $(8.93 \mu \mathrm{g} / \mathrm{g} \mathrm{DW})$ whereas lutein was found only in red macroalgae $(9.57$ to $38.60 \mu \mathrm{g} / \mathrm{g} \mathrm{DW})$. In terms of total carotenoid content, green macroalgae contained the highest amount of carotenoid $(100.89 \pm 14.71 \mu \mathrm{g} / \mathrm{g} \mathrm{DW})$. The significant outcome of the research will be new natural carotenoid pigment sources as potential active pharmaceutical ingredients which can be beneficial to halal health-promoting products industry.
\end{abstract}

Keywords: Active pharmaceutical ingredients, carotenoid, macroalgae.

\section{INTRODUCTION}

Macroalgae or seaweed is classified into three different categories, which are red (Rhodophyta), brown (Phaeophyta), and green seaweed (Chlorophyta) [1]. The wide diversity of these marine algae offers a rich source of natural products and it contains a source of functional materials such as polyunsaturated fatty acids, polysaccharides, essential minerals and vitamins, antioxidants, enzymes and bioactive peptides [2-4]. In health-promoting products industry such as food, pharmaceutical, cosmetic, and biomedicine, macroalgae has been used as a valuable source of bioactive compounds such as phycocolloids, tocopherol, vitamin C, carotenoid and flavonoid [5-8]. Other than the potential nutritional values found in macroalgae, there are many reasons for macroalgae to be highly valuable such as cheap and economical, easily cultivated and adaptation to the extreme condition as well as has the potential to be boosted to meet global demand [9-11].

*Address correspondence to this author at the International Institute for Halal Research and Training (INHART), Herbarium Unit, Department of Landscape Architecture, Kulliyyah of Architecture and Environmental Design, International Islamic University Malaysia, 53100 Kuala Lumpur, Malaysia; Tel: +6012 6644772; Fax: +603 61964864; E-mail: rashidi@iium.edu.my

ISSN: 2223-3806 / E-ISSN: 1927-5951/19
Carotenoids are red, orange and yellow lipid soluble pigments that protect photosynthetic organisms against photooxidation by quenching oxygen radical species. Carotenoid is synthesized by all photosynthetic organisms including plants and some non-photosynthetic bacteria and fungi. The plant carotenoids are tetraterpenes derived from the 40-carbon isoprenoid phytoene [12]. Carotenoid is a valuable compound that is crucial to be used as added value products as it derived from natural raw material [13].

Previous study conducted by [14] reported that fucoxanthin, zeaxanthin, violaxanthin, and $\beta$-carotene were among the individual carotenoid pigments detected in macroalgae. There are plenty of functions of carotenoid such as the precursors of vitamin A and prevent human age-related macular degeneration as well as antioxidant properties [15]. Besides that, these pigments play an important role in health maintenance and have traditionally attracted the attention of the pharmaceutical and food industry. Carotenoid is widely used as colorants in the food and cosmetic industries, and some carotenoids are important supplements in livestock and fish feed formulations [16]. Therefore, this study aimed to identify carotenoid profiles from red, green and brown macroalgae species as new sources of potential halal active pharmaceutical ingredients. 


\section{MATERIALS AND METHODS}

\section{Sample Preparation}

All five species of red (Eucheuma denticulatum, Gracilaria tikvahiae, and Kappaphycus striatum), green (Caulerpa lentillifera) and brown (Padina pavonica) marine algae, were obtained from private seaweed plantation company, in Semporna, Sabah. The sample was washed with distilled water and cut to a smaller size $(50 \mathrm{~mm})$ and immediately stored at $-20^{\circ} \mathrm{C}$. The samples were freeze-dried for 7 days, after which the samples were ground into fine powder and stored at $80^{\circ} \mathrm{C}$ until further analysis.

\section{Extraction of Carotenoids}

The extraction procedure essentially follows the methods described by [17], with some modifications. $1.0 \mathrm{~g}$ of each powdered sample was rehydrated with distilled water and extracted with a mixture of acetone and methanol (7:3) at room temperature until colorless. The crude extracted was then centrifuged for $5 \mathrm{~min}$ at $10000 \mathrm{~g}$ and stored at $4^{\circ} \mathrm{C}$ in the dark prior to analysis. To extract carotenoids an equal volume of hexane and distilled water was added to the combined supernatants. The solution was then allowed to separate and the upper layer containing the carotenoids was collected. The combined upper phase was then dried to completion under a gentle stream of oxygen-free nitrogen

\section{Saponification}

Samples were saponified with a mixture of acetonitrile and water (9:1) and methanolic potassium hydroxide solution $(10 \% \mathrm{w} / \mathrm{v})$. Base carotenoids were then extracted by addition of $2 \mathrm{ml}$ hexane with $0.1 \%$ butylated hydroxytoluene (BHT), followed by addition of $10 \% \mathrm{NaCl}$ until phase separation was achieved. The extracts were washed with distilled water, dried under a gentle stream of oxygen-free nitrogen and resuspended in ethyl acetate for spectrophotometry and HPLC analysis [17].

\section{Determination of Total Carotenoid Content}

Total carotenoid concentration was determined by spectrophotometry according to the method described by [17]. The dried carotenoid was re-suspended in 500 $\mu \mathrm{L}$ of ethyl acetate for determination of total carotenoid content. For spectrophotometric analysis, $50 \mu \mathrm{L}$ of the re-dissolved sample was then diluted with $950 \mu \mathrm{L}$ chloroform. Three different wavelengths $\lambda ; 480 \mathrm{~nm}, 648$ $\mathrm{nm}$, and $666 \mathrm{~nm}$ were used in measuring the carotenoid-containing solutions using Varian Cary 50 UV-Vis spectrophotometer. The total carotenoid content in chloroform was obtained by using the Wellburn equation [18] as described below:

$\mathrm{Ca}=10.91 \mathrm{~A} 666-1.2 \mathrm{~A} 648$

$\mathrm{Cb}=16.36 \mathrm{~A} 648-4.57 \mathrm{~A} 666$

$C x+c=(1000 A 480-1.42 C a-46.09 C b) / 202(\mu \mathrm{g} / \mathrm{ml})(3)$

$\mathrm{Ca}=$ concentration of carotenoid at $666 \mathrm{~nm}, \mathrm{Cb}=$ concentration of carotenoid at $648 \mathrm{~nm}$, and $\mathrm{Cx}+\mathrm{C}=$ total carotenoid concentration at $480 \mathrm{~nm}$.

\section{HPLC Analysis of Carotenoids}

The HPLC analysis of carotenoids was performed on an Agilent model 1200 series comprised of a quaternary pump with autosampler injector, microdegassers, column compartment equipped with a thermostat and a diode array detector. The column used was a ZORBAX Eclipse XDB- $\mathrm{C}_{18}$ end capped 5 $\mu \mathrm{m}, 4.6 \times 150 \mathrm{~mm}$ reverse phase column (Agilent Technologies, USA). The eluents used were (A) acetonitrile: water $(9: 1 \mathrm{v} / \mathrm{v})$ and $(B)$ ethyl acetate. The column separation was allowed via a series of gradient such as follows: $0-40 \%$ solvent $B(0-20 \mathrm{~min}), 40-60 \%$ solvent B (20-25 min), $60-100 \%$ solvent B (25-25.1 $\mathrm{min}), 100 \%$ solvent $B(25.1-35 \mathrm{~min})$ and $100-0 \%$ solvent $B(35-35.1 \mathrm{~min})$ at a flow rate of $1.0 \mathrm{~mL} \mathrm{~min}^{-1}$. The column would be allowed to re-equilibrate in $100 \%$ A for 10 min prior to the next injection. The temperature of the column was maintained at $20^{\circ} \mathrm{C}$. The injection volume is $10 \mu \mathrm{L}$ each. Detection of individual carotenoids was made at the wavelengths of maximum absorption of the carotenoids in the mobile phase: neoxanthin (438 nm), violaxanthin (441 nm), lutein (447 $\mathrm{nm})$, zeaxanthin $(452 \mathrm{~nm}), \beta$-carotene $(454 \mathrm{~nm}), \beta$ cryptoxanthin $(450 \mathrm{~nm})$ and $\alpha$-carotene (456 nm). Compounds were identified by co-chromatography with standards and by elucidation of their spectral characteristics using a photo-diode array detector. Detection for carotenoid peaks was in the range of 350 to $550 \mathrm{~nm}$. Individual carotenoid concentrations were calculated by comparing their relative proportions, as reflected by integrated HPLC peak areas, to total carotenoid content determined by spectrophotometry. The total and individual carotenoid concentration would be expressed in terms of a milligram per $1.0 \mathrm{~g}$ dry weight of freeze-dried matter ( $\mu \mathrm{g} / \mathrm{g} \mathrm{DW})$.

\section{Statistical Analysis}

All measurements were calculated in triplicates $(n=3)$ and the values were averaged with standard 
deviation ( $\pm S D)$. Statistical analysis was completed by using Statistical Analysis Software (SAS). The differences between the means were analysed by ANOVA test followed by Tukey's post-hoc test. A significant difference was considered at the level of $\mathrm{P}<$ 0.0001 .

\section{RESULTS AND DISCUSSION}

Five species from three groups of marine macroalgae which are E. denticulatum (Rhodophyta), G. tikvahiae (Rhodophyta), K. striatum (Rhodophyta), C. lentillifera (Chlorophyta), and $P$. pavonica (Phaeophyta) were selected and analysed for carotenoid content and composition to determine the types of macroalgae group based on carotenoid accumulation. The analysis of variance established significant to highly significant differences between the five species, the three algae groups and their interaction for all the carotenoid content and composition (Table 1). Analysis of individual carotenoid profiles in the 3 different groups of macroalgae harvested in 2016 revealed that only four major carotenoids were detected (violaxanthin, zeaxanthin, lutein and $\beta$-carotene). Comparison of carotenoid profiles of these 3 groups also showed variations in individual carotenoid composition and content. Zeaxanthin, lutein and $\beta$-carotene were detected (Figures 1-3) in red macroalgae species (Table 1), whereas in green macroalgae species violaxanthin, zeaxanthin and $\beta$-carotene were detected (Figure 4), but lutein was absent. Interestingly only zeaxanthin and $\beta$-carotene were found in brown macroalgae species (Figure 5) with the absence of violaxanthin and lutein. These data highlight the major effect the genotype can have on the presence and accumulation of carotenoid compounds. The importance of the interaction components emphasises that the changes in carotenoid composition are complex and the responses are not consistent across red, green and brown macroalgae species group. The $C$. lentillifera (100.89 $\mu \mathrm{g} / \mathrm{g} D W$ ) was detected to have the highest amount of carotenoid content and G. tikvahiae $(25.13 \mu \mathrm{g} / \mathrm{g} \mathrm{DW})$ was the lowest. Of the five genotypes analysed, $K$. striatum was detected with high lutein $(38.60 \mu \mathrm{g} / \mathrm{g} \mathrm{DW})$ whereas $C$. lentillifera was detected with high

Table 1: Total and Individual Carotenoid Content ( $\mu \mathrm{g} / \mathrm{g}$ DW) and Composition of Red, Green and Brown Macroalgae Species

\begin{tabular}{|c|c|c|c|c|c|}
\hline Species & $\begin{array}{l}\text { Total Carotenoid } \\
(\mu \mathrm{g} / \mathrm{g} \text { DW })\end{array}$ & $\begin{array}{c}\text { Lutein } \\
(\mu g / g \text { DW })\end{array}$ & $\begin{array}{l}\text { Violaxanthin } \\
(\mu \mathrm{g} / \mathrm{g} D W)\end{array}$ & $\begin{array}{c}\text { Zeaxanthin }(\mu \mathrm{g} / \mathrm{g} \\
\text { DW) }\end{array}$ & $\begin{array}{c}\beta \text {-Carotene } \\
(\mu \mathrm{g} / \mathrm{g} D W)\end{array}$ \\
\hline \multicolumn{6}{|c|}{ Red Macroalgae Species } \\
\hline Eucheuma denticulatum & $33.02 \pm 6.91^{\mathrm{bc}}$ & $9.57 \pm 0.64^{\mathrm{a}}$ & - & $3.61 \pm 0.24^{c}$ & $2.44 \pm 0.26^{a}$ \\
\hline Gracilaria tikvahiae & $25.13 \pm 9.42^{c}$ & $8.86 \pm 0.63^{\mathrm{a}}$ & - & $4.15 \pm 0.17^{c}$ & $3.05 \pm 0.55^{a}$ \\
\hline Kappaphycus striatum & $57.02 \pm 15.82^{b c}$ & $38.60 \pm 6.30^{a}$ & - & $4.47 \pm 0.21^{c}$ & $7.59 \pm 2.04^{a}$ \\
\hline \multicolumn{6}{|c|}{ Green Macroalgae Species } \\
\hline Caulerpa lentillifera & $100.89 \pm 14.71^{\mathrm{a}}$ & - & $8.93 \pm 1.07^{\mathrm{a}}$ & $21.30 \pm 3.64^{a}$ & $10.70 \pm 3.66^{a}$ \\
\hline \multicolumn{6}{|c|}{ Brown Macroalgae Species } \\
\hline Padina pavonica & $56.82 \pm 28.29^{\mathrm{ab}}$ & - & - & $10.87 \pm 0.95^{b}$ & $9.15 \pm 0.65^{a}$ \\
\hline
\end{tabular}

*Value (means) with different superscripts are significantly different from one another $(p<0.0001)$.

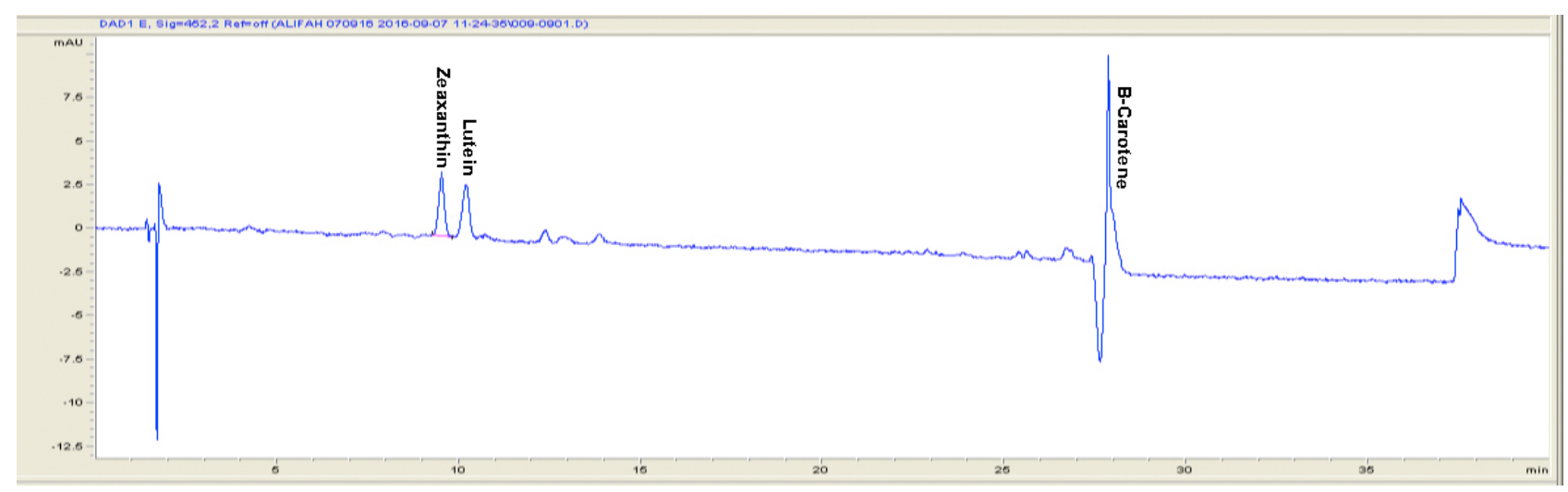

Figure 1: HPLC chromatorgram of zeaxanthin, lutein and $\beta$-carotene in $E$. denticulatum. 


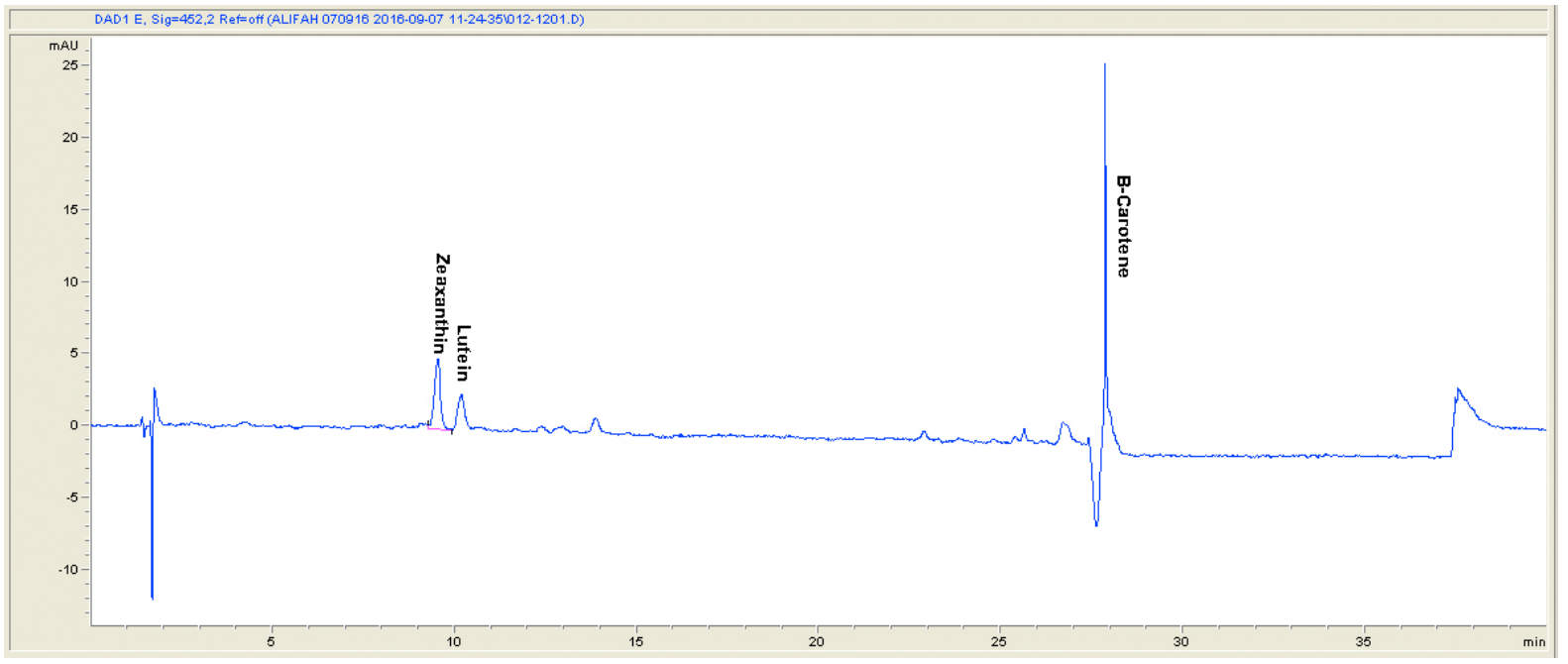

Figure 2: HPLC chromatorgram of zeaxanthin, lutein and $\beta$-carotene in G. tikvahiae.

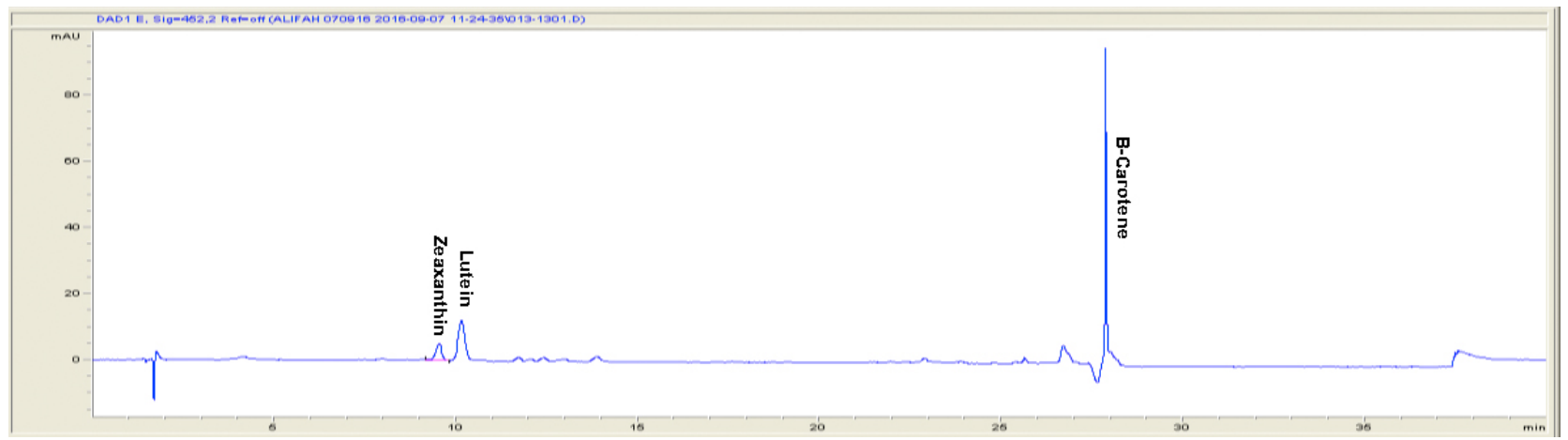

Figure 3: HPLC chromatorgram of zeaxanthin, lutein and $\beta$-carotene in $K$. striatum.

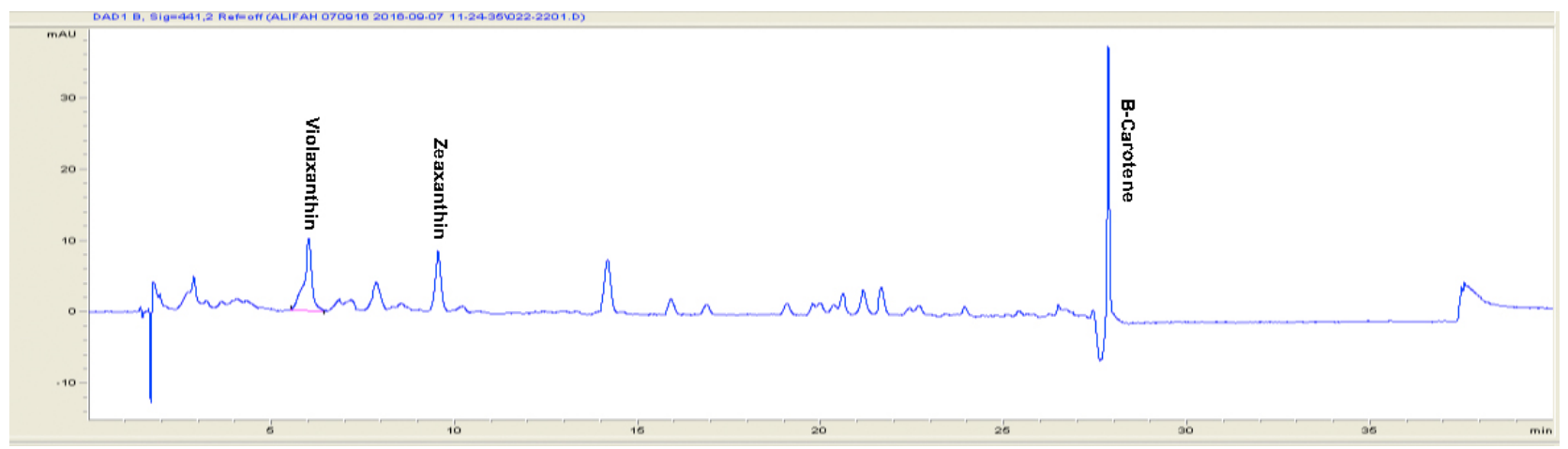

Figure 4: HPLC chromatorgram of violaxanthin, zeaxanthin, and $\beta$-carotene in C. lentillifera.

violaxanthin $(8.93 \mu \mathrm{g} / \mathrm{g} \mathrm{DW})$, zeaxanthin $(21.30 \mu \mathrm{g} / \mathrm{g}$ DW) and $\beta$-carotene (10.70 $\mu \mathrm{g} / \mathrm{g} \mathrm{DW})$ (Table 1).

Brown macroalgae is rich in carotenoids especially fucoxanthin, $\beta$-carotene and violaxanthin; red macroalgae was rich in $\beta$-carotene, $\alpha$-carotene, zeaxanthin and lutein whereas green macroalgae species accumulated $\beta$-carotene, lutein, violaxanthin, antheraxanthin, zeaxanthin and neoxanthin $[19,20]$. However, in this study, only zeaxanthin and $\beta$-carotene were detected in brown macroalgae species whereas in red macroalgae only $\beta$-carotene, zeaxanthin and lutein were found. In contrast, green macroalgae in this study accumulated merely $\beta$-carotene, violaxanthin and zeaxanthin. Surprisingly, $C$. lentillifera result was in accordance to the previous study which detected the amount of $\beta$-carotene content in $C$. lentillifera (green macroalgae) was higher than $E$. denticulatum (red macroalgae) [21]. Brown macroalgae was also found to have substantially highest carotenoid content followed 


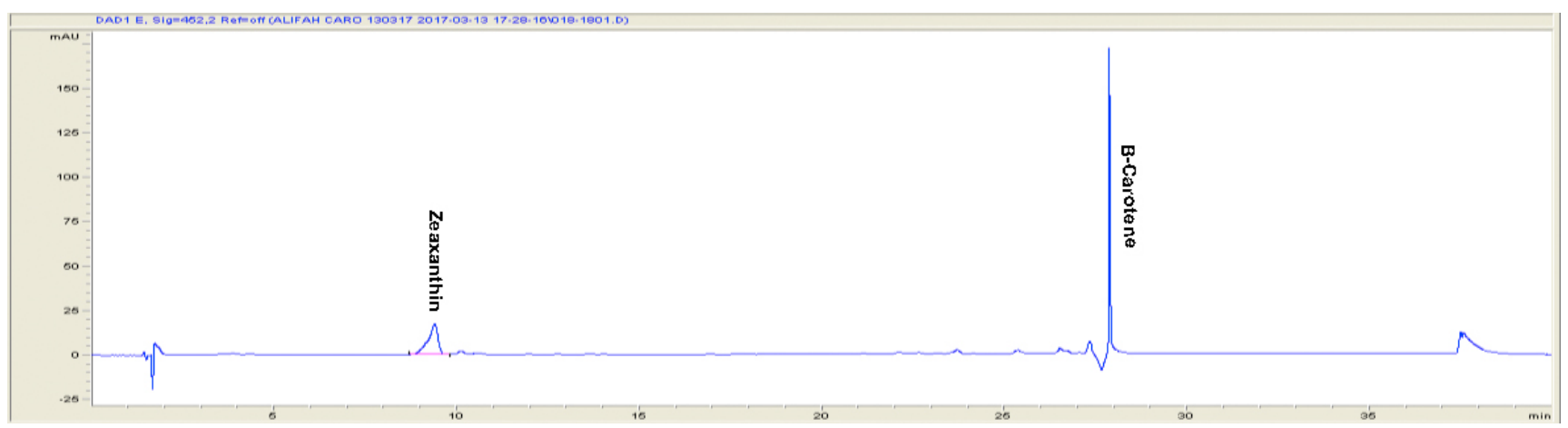

Figure 5: HPLC chromatorgram of zeaxanthin and $\beta$-carotene in P. pavonica.

by red and green macroalgae species [22, 23]. In contrast, our results showed that the total amount of carotenoid content was higher in green macroalgae compared with red and brown species.

\section{CONCLUSION}

Seaweed or marine algae are the largest producers in the oceanic environment which harbours potential source of diverse and valuable compounds. Seaweed extracts and powder have exhibited bioactive responses as antioxidant, antibacterial and antifungal agents. These positive activities were observed in all seaweed genera encompassing of red, green and brown algae species. The presence of bioactive compounds in seaweed offers a great opportunity for them to be used as anticancer, antimicrobial and Active Pharmaceutical Ingredient (API). This is mainly due to the fact that seaweed has health benefits and properties that are similar to animal-based products. Moreover, pigments extracted from these macroalgae can be used as natural colourants especially in the food industry that is guaranteed to be safe and halal. They can potentially substitute the synthetic colourant that are commercially used by large industrial players.

\section{ACKNOWLEDGEMENT}

This work was supported by Ministry of Higher Education (MOHE) and International Islamic University Malaysia (IIUM) under Research Grant RPDF18-0060006.

\section{REFERENCES}

[1] Dawczynski C, Schubert R, Jahreis, G. Amino acids, fatty acids, a dietary fibre in edible seaweed products. Food Chem 2007; 103: 891-899.

https://doi.org/10.1016/j.foodchem.2006.09.041

[2] Thirunavukkarasu $\mathrm{P}$, Pandiyan D, Balaraman $\mathrm{K}$, Subaramaniyan GEG, \& Gnana Jothi, Sakthivel Manikkam BS. Thirunavukkarasu R, Pandiyan $\mathrm{P}$, Balaraman $\mathrm{D}$, Subaramaniyan K, Jothi GEG, Manikkam S, Sadaiyappan, B. Isolation of bioactive compound from marine seaweeds against fish pathogenic bacteria Vibrio alginolyticus (VA09) and characterisation by FTIR. J Coast Life Med 2013; 1(1): 26-33.

[3] Shanab SMM, Shalaby EA, El-Fayoumy, EA. Enteromorpha compressa exhibits potent antioxidant activity. J Biomed Biotechnol 2011; 2011: 1-11. https://doi.org/10.1155/2011/726405

[4] Neelamathi E, Kannan, R. Screening and Characterization of Bioactive Compounds of Turbinaria ornata from the Gulf of Mannar, India. Int Adv Res J Sci Eng Tech 2015; 16(2): 243251.

[5] Rauha JP, Remes S, Heinonen M, Hopia A, Kähkönen M, Kujala T, Pihlaja K, Vuorela H, Vuorela, P. (2000). Antimicrobial effects of Finnish plant extracts containing flavonoids and other phenolic compounds. Int $\mathrm{J}$ Food Microbiol 2000; 56(1): 3-12.

https://doi.org/10.1016/S0168-1605(00)00218-X

[6] Muhamad SAS, Jamilah B, Russly AR, Faridah, A. In vitro antibacterial activities and composition of Carica papaya cV. Sekaki/ Hong Kong peel extracts. Int Food Res J 2017; 24(3): 976-984.

[7] Mohy El-Din SM, El-Ahwany, AMD. Bioactivity and phytochemical constituents of marine red seaweeds (Jania rubens, Corallina mediterranea and Pterocladia capillacea). J Taibah Univ Sci 2016; 10(4): 471-484. https://doi.org/10.1016/j.jtusci.2015.06.004

[8] Azwanida NN, Hui MS, Afandi A, Mohamed S, Zulhisyam AK, Ayob A, Rusli N, Mat Rasat MS, Mohamed, M. Color Stability Evaluation of Pigment Extracted from Hylocereus polyrhizus, Clitorea ternatae and Pandanus amaryllfolius as Cosmetic Colorants and Premarket Survey on Customer Acceptance on Natural Cosmetic Product. J Trop Resour Sustain Sci 2015; 3(5): 61-67.

[9] Neish AS. Microbial interference with host inflammatory responses. In: Microbial pathogenesis and the intestinal epithelial cell. ASM Press 2003; p.175-190. https://doi.org/10.1128/9781555817848.ch11

[10] Koller M, Muhr A, Braunegg Hurtado AQ. Seaweed production: Farming Kappaphycus in the Philippines. Global Aquaculture Advocate 2002; 5(2): 68-69.

[11] Wenno PA, Syamsuddin R, Jamal, E. Growth and Carrageenan from Kappaphycus alvarezii (Doty) at Different Depths and Their Possible Application in Other Locations. Aquac Indones 2016; 17(1): 20-25. https://doi.org/10.21534/ai.v17i2.58

[12] Ruiz-Sola MA, Rodríguez-Concepción, M. Carotenoid biosynthesis in Arabidopsis: a colorful Pathway. Arabidopsis Book. American Society of Plant Biologists, US 2012.

[13] Moran NA, Jarvik, T. Lateral transfer of genes from fungi underlies carotenoid production in aphids. Science 2010; 328(5978): 624-627. https://doi.org/10.1126/science. 1187113

[14] Maeda H, Tsukui T, Sashima T, Hosokawa M, Miyashita, K. Seaweed carotenoid, fucoxanthin, as a multi-functional nutrient. Asia Pac J Clin Nutr 2008; 17(1):196-199. 
[15] Cox S, Abu Gannam N, Gupta, S. An assessment of the antioxidant and antimicrobial activity of six species of edible Irish seaweeds. Int Food Res J 2010; 17(1): 205-220.

[16] de Alencar DB, de Carvalho FCT, Reboucas RH, dos Santos DR, dos Santos Pires-Cavalcante KM, de Lima RL, Baracho BM, Bezerra RM, Viana FA, dos Fernandes Vieira RHS, Sampaio AH, de Sousa OV, Sampaio, SS. Bioactive extracts of red seaweeds Pterocladiella capillacea and Osmundaria obtusiloba (Floridophyceae: Rhodophyta) with antioxidant and bacterial agglutination potential. Asian Pac J Trop Med 2016; 9(4): 372-379.

https://doi.org/10.1016/i.apitm.2016.03.015

[17] Othman R, Noh NH, Mohd Hatta FA, Jamaludin, MA. Natural carotenoid pigments of 6 chlorophyta freshwater green algae species. J Pharm Nutri Sci 2018; 8(1): 1-5. https://doi.org/10.6000/1927-5951.2018.08.01.1

[18] Wellburn AR. The Spectral Determination of Chlorophylls a and $b$, as well as Total Carotenoids, Using Various Solvents with Spectrophotometers of Different Resolution. J Plant Physiol 1994; 144(3): 307-313.

https://doi.org/10.1016/S0176-1617(11)81192-2
[19] Burtin P. Nutritional Value of Seaweeds. Electron J Environ Agric Food Chem 2003; 2(4): 498-503.

[20] Diyana F, Hisham S, Chan K, Abdullah, A. Antioxidant activity of red algae Kappaphycus alvarezii and Kappaphycus striatum. Int Food Res J 2015; 22(5): 1977-1984.

[21] McDermid KJ, Stuercke, B. Nutritional composition of edible Hawaiian seaweeds, J Appl Phycol 2003; 15(6): 513-524. https://doi.org/10.1023/B:JAPH.0000004345.31686.7f

[22] Chakraborty S, Santra, SC. Biochemical composition of eight benthic algae collected from Sunderban. Indian J Mar Sci 2008; 37(3): 329-332.

[23] Perez MJ, Falque E, Domínguez, H. Antimicrobial Action of Compounds from Marine Seaweed. Mar Drugs 2016; 14(3): 52. https://doi.org/10.3390/md14030052 